\title{
Persepsi Masyarakat Terhadap Usaha Kerupuk Amplang (Studi Kasus Kelompok Wanita Mandiri Desa Pambang Pesisir- Bengkalis)
}

\author{
RETNI PRAMADITA ${ }^{1}$, NAZRANTIKA SUNARTO ${ }^{2}$ \\ Politeknik Negeri Bengkalis \\ J1. Bathin Alam Sungai Alam-Bengkalis-Riau 28711 Telp. (0766) 7008877 Fax. (0766) 8001000 \\ Email: nazrantika@polbeng.ac.id
}

\begin{abstract}
The purpose of this study is to determine the response of the community about the marketing mix conducted on Amplang Cracker Business (Case Study of Independent Women's Group of Pambang Pesisir Village). The results of this study indicate that from each indicator statement amounting to 4 indicators with 8 statements, then obtained the total value for marketing mix variables that is as much as 4.25 which means the marketing mix is done with very high category. Public response about Marketing Mix Variables is the most dominant is the promotion with a total mean 4.50 with a very high category which means people are interested in promotions made either directly or via social media. For the smallest of each indicator is the price with a mean total of 4.13 with a high category which means that the selling price of offered is not in accordance with the quality of the product and the low price of the competitor products may not be able to control a larger market share.
\end{abstract}

Keywords: Marketing Mix, Community Response, UKM

Usaha Kecil, dan Menengah (UKM) memiliki peran penting dalam perekonomian Indonesia dengan terciptanya lapangan kerja baru bagi masyarakat. Meski skala kecil, namun perannya sangat berarti dalam upaya turut menopang perekonomian nasional dan menciptakan banyak lapangan kerja baru. Walaupun seseorang tidak punya keterampilan sama sekali, namun mereka bebas memilih apa saja yang ingin ditekuni.

Selain masalah permodalan, dalam membangun sebuah kecil seseorang hanya butuh tekad dan keseriusan dalam membangun usahanya. Hal ini menjadi bukti atas potensi UKM dalam pemulihan krisis ekonomi, untuk mengurangi permasalahan kemiskinan dan pengembangannya mampu memperluas basis ekonomi serta dapat memberikan kontribusi dalam meningkatkan perekonomian. Hal inilah menunjukkan bahwa selain sebagai penangkal krisis juga memiliki peran yang sangat strategis dalam ekonomi suatu negara.

Riau sebagai provinsi yang memiliki iklim bisnis tinggi juga memiliki perkemba ngan yang cukup baik. Menurut data Dinas
Koperasi dan UKM Riau Tahun 2016 dapat dilihat pada tabel di bawah ini:

Tabel 1. Data UMKM Kabupaten/Kota Se-Riau

\begin{tabular}{|l|l|r|}
\hline No. & $\begin{array}{l}\text { Nama } \\
\text { Kabupaten/Kota }\end{array}$ & $\begin{array}{r}\text { Jumlah } \\
\text { UKM }\end{array}$ \\
\hline 1. & Pekanbaru & 68.728 \\
\hline 2. & Kampar & 45.446 \\
\hline 3. & Indragiri Hilir & 44.891 \\
\hline 4. & Bengkalis & 42.029 \\
\hline 5. & Rokan Hilir & 34.036 \\
\hline 6. & Rokan Hulu & 27.074 \\
\hline 7. & Indragiri Hulu & 26.488 \\
\hline 8. & Siak & 22.948 \\
\hline 9. & Kuansing & 21.450 \\
\hline 10. & Dumai & 20.782 \\
\hline 11. & Pelalawan & 13.824 \\
\hline
\end{tabular}

Sumber Data : Dinas Koperasi dan UKM Riau, 2016

Berdasarkan Tabel 1 bahwa kota Pekanbaru menempati posisi pertama dengan jumlah UMKM. Posisi kedua adalah Kampar dan Indragiri Hilir menempati posisi ketiga. Selanjutnya, Bengkalis diposisi keempat, Rokan Hilir, Rokan Hulu, Indragiri Hulu, Siak, Kuansing, Dumai dan Pelalawan 
menempati posisi juru kunci. Dari sejumlah UMKM yang tersebar di seluruh kabupaten/kota se-Riau itu memiliki total keseluruhan (367.696 UMKM), sektor perdagangan dengan (77.156 UMKM) menjadi sektor paling diminati dibandingkan dengan jasa (19.656 UMKM), produksi (12.760 UMKM) dan industri dengan (11.320 UMKM). Data UMKM tersebut sangat berguna untuk pengelompokkan UKM sesuai bidangnya dan guna mengetahui lebih detail pertumbuhan UKM. Angka di atas terus meningkat seiring dengan perkembangan pembangunan daerah yang semakin maju.

Kabupaten Bengkalis merupakan salah satu kabupaten dengan letak geografis yang strategis pada lokasi perikanan, serta didukung dengan kondisi alam yang sangat potensial. Kabupaten Bengkalis sangat memungkinkan mengembangkan investasi terutama dalam bidang perikanan dan kelautan. Melihat produksi ikan yang tinggi, kondisi ini sangat menunjang untuk melakukan usaha pengolahan ikan di Desa Pambang Pesisir. Desa Pambang Pesisir adalah bagian dari wilayah Desa Teluk Pambang hasil pemekaran. Salah satu industri yang memiliki potensi untuk dikembangkan di Kabupaten Bengkalis adalah industri Kerupuk Ikan Tenggiri (Scomberemus commersoni). Sehubungan dengan hal tersebut, desa Pambang Pesisir menciptakan kelompok demi kelompok untuk berlomba-lomba dalam pembuatan produk kerupuk amplang, tetapi kurangnya melakukan pemasaran antar setiap kelompok sehingga produk yang diciptakan kurang dikenali oleh masyarakat luas. Perlu adanya pendekatan kepada masyarakat yang bersangkutan dalam kelompokkelompok usaha untuk membuat dan meyakinkan masyarakat agar usaha yang ada menjadi usaha yang lebih maju dalam sebuah industri kecil, dengan lebih gencar lagi dalam melakukan pemasaran sehingga bisa melakukan produksi dalam jumlah yang lebih besar. Berdasarkan hasil wawancara pada ketua kelompok Wanita Mandiri Ibu Zaitun di Pambang Pesisir pada awalnya produksi hanya dilakukan pada saat ada pesanan dan pameranpameran saja serta kurangnya melakukan pemasaran, sehingga dengan adanya penelitian melalui persepsi masyarakat pada produk ini, produksi bisa dilakukan dalam jumlah besar bahkan bisa setiap hari karena telah dilakukan pemasaran sehingga masyarakat luas lebih banyak mengenali produk kerupuk amplang ini dan bisa menjadikan kerupuk amplang sebagai oleh-oleh Bengkalis.

Dalam melakukan usaha industri kerupuk amplang perlu dilakukan bauran pemasaran yang tepat agar kerupuk amplang mendapatkan omset penjualan yang relatif bagus. Menurut Kotler dan Keller dalam Praja (2015) menyimpulkan bahwa bauran pemasaran merupakan satu perangkat yang terdiri dari produk, harga, promosi dan distribusi, yang di dalamnya akan menentukan tingkat keberhasilan pemasaran dan semua itu ditujukan untuk mendapatkan respon yang diinginkan dari pasar sasaran. Dalam hal pemasaran pengaruh kemasan produk, harga jual, media iklan di media sosial dan sebagainya mempengaruhi persepsi seseorang terhadap suatu produk atau merek, cara pandang seorang konsumen terhadap suatu produk apakah produk tersebut baik atau buruk secara kualitas, harga, bentuk, dan manfaat sebelum ia mengambil keputusan pembelian. Memahami proses persepsi sangat penting bagi pemasar agar dapat menciptakan komunikasi yang efektif dengan konsumen. Hal utama yang perlu disadari adalah apa saja sebenarnya yang diharapkan oleh para pembeli dengan membayarkan sejumlah uang tertentu untuk membeli hasil produk tersebut.

Dengan penelitian ini diharapkan dapat memberikan gambaran kepada seluruh pemilik usaha untuk menjadikan usahanya lebih berkembang dan lebih maju dengan tahu bagaimana tanggapan konsumen terhadap produk.

yang ditawarkan. Di lain pihak, diharapkan hasil-hasil industri dapat 
diserap oleh masyarakat sehingga selain memberikan keuntungan finansial juga dapat memberikan perluasan kesempatan kerja dan lapangan kerja serta menambah pendapatan. Dari uraian-uraian di atas maka penulis membuat suatu penelitian akhir dengan judul yang akan dilaksanakan adalah "Persepsi Masyarakat Terhadap Usaha Kerupuk Amplang (Studi Kasus Kelompok Wanita Mandiri Desa Pambang Pesisir)".

Manajemen pemasaran akan terjadi apabila sekurang-kurangnya satu pihak dari pertukaran potensial memikirkan cara untuk mendapatkan tanggapan dari pihak lain sesuai dengan yang diinginkannya. American Marketting Association (AMA) menjelaskan dalam A.D Selang (2013) bahwa manajemen pemasaran sebagai seni dan ilmu memilih pasar sasaran dan mendapatkan, menjaga, dan menumbuhkan pelanggan dengan menciptakan, menyerahkan, dan mengkomunikasikan nilai pelanggan yang unggul. Sesuai dengan definisi tersebut, Kotler dan Keller dalam A.D Selang (2013) menyimpulkan bahwa manajemen pemasaran merupakan suatu proses yang dimulai dari proses perencanaan, pengarahan, dan pengendalian produk atau jasa, penetapan harga, distribusi, dan promosinya dengan tujuan membantu organisasi dalam mencapai tujuannya.

Menurut Evan dan Berman dalam Ginting (2011:10) strategi pemasaran merangkum cara-cara dimana bauran pemasaran disyukuri untuk menarik dan memuaskan pasar sasaran dan sekaligus mewujudkan tujuan perusahaan. Menurut pendapat Assauri (2010:168) strategi pemasaran pada dasarnya adalah rencana yang menyeluruh, terpadu dan menyatu di bidang pemasaran yang memberikan panduan tentang kegiatan yang akan dijalankan untuk dapat tercapainya tujuan pemasaran suatu perusahaan. Jadi, strategi pemasaran adalah rencana menyeluruh, terpadu dan menyatu di bidang pemasaran untuk memilih dan menganalisis target pasar, mengembangkan dan memelihara bauran pemasaran yang dapat memuaskan kebutuhan dan keinginan konsumen.

Menurut Kotler dan Amstrong dalam Praja (2015) definisi bauran pemasaran atau yang lebih dikenal dengan marketing mix adalah kumpulan alat pemasaran taktis terkendali yang dipadukan perusahaan untuk menghasilkan respons yang diinginkan dipasar sasaran. "Marketing mix adalah perangkat alat pemasaran yang digunakan perusahaan untuk mengejar tujuan perusahaannya.

Kotler dan Keller dalam Praja (2015) menyimpulkan bahwa bauran pemasaran merupakan satu perangkat yang terdiri dari produk, harga, promosi dan distribusi, yang di dalamnya akan menentukan tingkat keberhasilan pemasaran dan semua itu ditujukan untuk mendapatkan respon yang diinginkan dari pasar sasaran. Variabel-variabel tersebut dapat dikelompokkan menjadi empat kelompok utama yang dikenal dengan 4P, yaitu Product (Produk). Price (Harga), Promotion (Promosi) dan Place (Tempat atau Distribusi).

\section{METODE}

Penelitian ini dilakukan pada konsumen kerupuk amplang kelompok Wanita Mandiri Desa Pambang Pesisir, Kecamatan Bantan, Kabupaten BengkalisRiau. Jenis data yang digunakan dalam penelitian ini, yaitu data kuantitatif. Menurut Sugiyono (2013:15) data kuantitatif adalah data yang berbentuk angka, atau data kualitatif yang diangkakan (skoring: sangat setuju $=5$, setuju $=4$, raguragu $=3$, tidak setuju $=2$ dan sangat tidak setuju=1). Pada penelitian ini data kuantitatifnya adalah angka-angka yang diambil dari hasil pengisian kuesioner oleh responden.

Data primer adalah data yang diperoleh langsung dari responden atau sumbernya dengan objek penelitian yang dilakukan. Data ini berupa tanggapan hasil pembagian kuesioner peneliti dengan responden. Disini data primer atau data 
yang diperoleh langsung dari responden adalah data mengenai tanggapan masyarakat tentang bauran pemasaran pada kerupuk amplang Kelompok Wanita Mandiri Desa Pambang Pesisir.

Menurut Sugiyono (2014:85) teknik sampling merupakan teknik pengambilan sampel. Teknik sampling pada penelitian ini adalah menggunakan sampling jenuh, yaitu teknik penentuan sampel bila semua anggota populasi digunakan sebagai sampel. Hal ini sering dilakukan bila jumlah populasi relatif kecil, kurang dari 30 orang, atau penelitian yang ingin membuat generalisasi dengan kesalahan yang sangat kecil. Istilah lain sampel jenuh adalah sensus, dimana semua anggota populasi dijadikan sampel.

Dalam penelitian ini, teknik pengumpulan data yang digunakan untuk memperoleh data dalam penelitian ini adalah sebagai berikut: Kuesioner merupakan teknik pengumpulan data yang dilakukan dengan cara memberi seperangkat pertanyaan atau pernyataan tertulis kepada responden untuk dijawabnya (Sugiyono, 2012:199). Hal ini diberikan kepada masyarakat yang sudah pernah mengkonsumsi kerupuk amplang kelompok Wanita Mandiri. Pengumpulan data berikutnya dengan melakukan wawancara dengan cara mengajukan tanya jawab secara langsung. Wawancara digunakan sebagai teknik pengumpulan data apabila peneliti ingin melakukan studi pendahuluan untuk menemukan permasalahan yang harus diteliti, dan juga apabila peneliti ingin mengetahui hal-hal dari responden yang lebih mendalam (Sugiyono, 2012:194). Hal ini untuk membantu peneliti untuk menanyakan calon responden apakah mereka pernah mengkonsumsi kerupuk amplang kelompok Wanita mandiri dan membantu respnden jika mengalami kesulitan dalam pengisian kuesioner.

Menurut Sugiyono (2014:80) populasi adalah wilayah generalasi yang terdiri atas objek/subyek yang mempunyai kualitas dan karakteristik tertentu yang ditetapkan oleh peneliti untuk dipelajari dan kemudian ditarik kesimpulannya. Untuk keperluan penelitian diperlukan sekelompok orang dalam satu wilayah yang diteliti (populasi) untuk diberikan kuesioner yang berisi sejumlah pertanyaan berdasarkan indikator dan variabel yang diteliti. Populasi dari penelitian ini adalah para konsumen yang pernah mengkonsumsi kerupuk amplang Kelompok Wanita Mandiri Desa Pambang Pesisir.

Menurut Sugiyono (2014:80) sampel adalah bagian dari jumlah dan karakteristik yang dimiliki oleh populasi tersebut. Populasi yang dapat dijadikan sampel penelitian diharapkan dapat mewakili seluruh elemen penelitian. Dalam hal ini yang menjadi sampel penelitian sebanyak 30 orang konsumen. Alasan mengambil sampel 30 orang selain sudah memenuhi kriteria minimal penelitian juga karena keterbatasan waktu pengambilan sampel sehingga tidak memungkinkan untuk mendapatkan sampel lebih banyak.

Jenis penelitian yang digunakan peneliti dalam penelitian ini adalah jenis penelitian observasional, yaitu penelitian yang bertujuan untuk mengetahui persepsi pelanggan dari variabel yang diteliti. Disini penulis meneliti tentang tanggapan masyarakat tentang bauran pemasaran pada kerupuk amplang Kelompok Wanita Mandiri Desa Pambang Pesisir.

Dalam penelitian ini peneliti menggunakan pengukuran skala likert yaitu skala yang digunakan untuk mengukur sikap dan pendapat serta persepsi seseorang atau kelompok orang tentang fenomena yang terjadi. Dengan skala likert, maka variabel yang akan diukur dijabarkan menjadi indikator variabel. Kemudian indikator tersebut dijadikan titik tolak untuk menyusun instrument yang dapat berupa pertanyaan atau pernyataan. Jawaban dari setiap instrument yang menggunakan skala Likert mempunyai gradasi dari sangat positif sampai sangat negatif. Untuk memperluas analisis kualitatif, maka jawaban itu akan diberikan skor (nilai).

\section{HASIL}

Hasil tanggapan masyarakat mengenai bauran pemasaran yang 
dilakukan pada Usaha Kerupuk Amplang (Studi Kasus Kelompok Wanita Mandiri Desa Pambang Pesisir) dari 8 pernyatan dibawah ini: bahwa responden berpendapat setuju mengenai pernyataan kerupuk amplang dikemas dengan desain dan label yang menarik serta permilihan bahan kemasan yang tepat untuk produk kerupuk amplang Kelompok Wanita Mandiri dapat diasumsikan bahwa ada kecenderungan dari responden berpendapat setuju sebanyak 14 orang dengan persentase sebesar $46,67 \%$ dari $100 \%$, hal ini dikarenakan dengan menggunakan desain kemasan dan label yang menarik dapat menambah nilai jual suatu produk sehingga membuat calon konsumen cenderung memiliki rasa penasaran untuk mencoba dengan membeli kerupuk amplang tersebut. Responden berpendapat sangat setuju mengenai pernyataan bentuk kerupuk amplang yang dihasilkan dapat bervariasi agar calon konsumen tidak bosan dengan bentuk biasa saja dapat diasumsikan bahwa ada kecenderungan dari responden berpendapat sangat setuju sebanyak 17 orang dengan persentase sebesar $56,67 \%$ dari $100 \%$.

Hal ini dikarenakan dengan adanya pilihan atau variasi bentuk kerupuk amplang dapat menjadi daya tarik untuk kerupuk amplang itu sendiri agar calon konsumen tidak bosan dengan bentuk yang sudah ada. Responden berpendapat sangat setuju mengenai pernyataan harga jual kerupuk amplang yang ditawarkan sesuai dengan kualitas produk yang didapat sehingga dapat diasumsikan bahwa ada kecenderungan dari responden berpendapat sangat setuju sebanyak 13 orang dengan persentase sebesar $43,33 \%$ dari $100 \%$, hal ini dikarenakan harga yang ditawarkan sesuai dengan kualitas produk yang didapat, walaupun harga yang ditawarkan sedikit lebih murah namun tidak mempengaruhi rasa dan kualitas kerupuk amplang yang ditawarkan. responden berpendapat setuju mengenai pernyataan penetapan harga yang rendah dibandingkan produk pesaing dapat menguasai pangsa pasar yang lebih besar namun tidak mengurangi kualitas yang ada. Dari uraian di atas dapat diasumsikan bahwa ada kecenderungan dari responden berpendapat setuju sebanyak 17 orang dengan persentase sebesar $56,67 \%$ dari $100 \%$, hal ini dikarenakan dengan penetapan harga yang sedikit rendah dapat menguasai pasar lebih besar dan dapat bersaing dengan kualitas produk kerupuk amplang lainnya. Responden berpendapat setuju mengenai pernyataan sistem penitipan di warungwarung dan toko dapat mempermudah konsumen dalam proses pembelian dapat diasumsikan bahwa ada kecenderungan dari responden berpendapat setuju sebanyak 17 orang dengan persentase sebesar $56,67 \%$ dari $100 \%$, hal ini dikarenakan dapat mempermudah dan menjangkau segala kalangan masyarakat untuk membeli produk kerupuk amplang dimanapun dan kapanpun tergantung pada tempat distribusi yang dituju. Responden berpendapat sangat setuju mengenai pernyataan analisis pasar terhadap produk yang ditawarkan dapat menghindari jumlah pesaing kerupuk amplang dapat diasumsikan bahwa ada kecenderungan dari responden berpendapat sangat setuju sebanyak 12 orang dengan persentase sebesar $40,00 \%$ dari $100 \%$, hal ini dikarenakan perlunya melakukan analisis pasar untuk melihat lebih jeli persaingan dan peluang pasar terutama kerupuk amplang sebelum melakukan pemasaran ke tempat yang ditentukan agar terhindar dari pesaing-pesaing kerupuk lainnya. Responden berpendapat setuju mengenai pernyataan pemasaran langsung dianggap paling efektif karena dapat terlibat langsung dengan calon konsumen dapat diasumsikan bahwa ada kecenderungan dari responden berpendapat setuju sebanyak 15 orang dengan persentase sebesar 50,00\% dari $100 \%$, hal ini dikarenakan promosi yang dilakukan secara langsung dengan calon konsumen dapat membuat calon konsumen lebih percaya pada produk yang ditawarkan karena tidak ada unsur penipuan apapun dengan tujuan untuk menarik calon konsumen agar membeli kerupuk amplang Kelompok Wanita Mandiri.

$$
\text { Responden berpendapat sangat }
$$


setuju mengenai pernyataan penggunaan media sosial dapat membantu mempromosikan kerupuk amplang kepada masyarakat dengan lebih mudah dapat diasumsikan bahwa ada kecenderungan dari responden berpendapat sangat setuju sebanyak 19 orang dengan persentase sebesar $63,33 \%$ dari $100 \%$, hal ini dikarenakan dengan memanfaatkan media sosial akan mempermudah dalam mempromosikan suatu produk dan dengan adanya media sosial masyarakat bisa mengetahui keberadaan suatu produk yang dipasarkan dengan lebih mudah.

\section{PEMBAHASAN}

Bahwa pernyataan pertama dari indikator pertama variabel bauran pemasaran mempunyai skor mean 3,87 yang berarti tingkat dari jawaban pertama yaitu kerupuk amplang dikemas dengan desain dan label yang menarik serta permilihan bahan kemasan yang tepat adalah tinggi, selanjutnya pernyataan kedua dari indikator pertama variabel bauran pemasaran mempunyai skor mean 4,47 yang berarti tingkat dari jawaban kedua yaitu bentuk kerupuk amplang yang dihasilkan dapat bervariasi agar calon konsumen tidak bosan dengan bentuk biasa saja adalah sangat tinggi.

Kemudian pernyataan ketiga dari indikator kedua variabel bauran pemasaran mempunyai skor mean 3,97 yang berarti tingkat dari jawaban ketiga dimana harga jual kerupuk amplang yang ditawarkan sesuai dengan kualitas produk yang didapat adalah tinggi, berikutnya pernyataan keempat dari indikator kedua variabel bauran pemasaran mempunyai skor mean 4,30 yang berarti tingkat dari jawaban keempat yakni penetapan harga yang rendah dibandingkan produk pesaing dapat menguasai pangsa pasar yang lebih besar namun tidak mengurangi kualitas yang ada adalah sangat tinggi.

Selanjutnya pernyataan kelima dari indikator ketiga variabel bauran pemasaran mempunyai skor mean 4,37 yang berarti bahwa tingkat dari jawaban kelima yaitu sistem penitipan di warung-warung dan toko dapat mempermudah konsumen dalam proses pembelian adalah sangat tinggi, kemudian pernyataan keenam dari indikator ketiga variabel bauran pemasaran mempunyai skor mean 4,03 yang berarti bahwa tingkat jawaban keenam mengenai analisis pasar terhadap produk yang ditawarkan dapat menghindari jumlah pesaing kerupuk amplang adalah tinggi.

Berikutnya pernyataan

ketujuh dari indikator keempat variabel bauran pemasaran mempunyai skor mean 4,37 yang berarti bahwa tingkat dari jawaban ketujuh tentang pemasaran langsung dianggap paling efektif karena dapat terlibat langsung dengan calon konsumen adalah sangat tinggi, dan pernyataan kedelapan dari indikator keempat variabel bauran pemasaran mempunyai skor mean 4,63 yang berarti bahwa tingkat dari jawaban kedelapan mengenai penggunaan media sosial dapat membantu mempromosikan kerupuk amplang kepada masyarakat dengan lebih mudah adalah sangat tinggi.

Dari seluruh indikator yang telah dinyatakan, dapat dilihat total skor mean yang diperoleh dari masing-masing pernyataan indikator tersebut yang berjumlah 4 indikator dengan 8 pernyataan, maka diperoleh total nilai untuk variabel bauran pemasaran yaitu sebanyak 4,25 yang artinya bauran pemasaran yang dilakukan pada Kerupuk Amplang Kelompok Wanita Mandiri Desa Pambang Pesisir dengan kategori sangat tinggi.

Dari hasil tersebut maka dapat dikatakan bahwa bauran pemasaran pada Usaha Kerupuk Amplang (Studi Kasus Kelompok Wanita Mandiri Desa Pambang Pesisir) yang dilakukan dari bulan Maret sampai dengan Mei 2017 di Kabupaten Bengkalis telah dilakukan dengan baik hal ini terbukti dari indikator dari variabel bauran pemasaran yang memiliki nilai tinggi dan sangat tinggi, hal ini tidak terlepas dari pemilihan produk, harga, tempat dan promosi yang dilakukan.

Dari keseluruhan variabel bauran 
pemasaran dari 4 indikator sangat tinggi, namun untuk promosi yang merupakan salah satu bauran pemasaran yang paling dominan dengan total mean 4,50 dengan kategori sangat tinggi yang artinya masyarakat tertarik dengan promosi yang dilakukan. Hal ini dikarenakan pemasaran kerupuk amplang Kelompok Wanita Mandiri dilakukan dengan terlibat langsung dengan calon konsumen dengan pemasaran secara langsung, selain itu juga penggunaan media sosial dapat membantu mempromosikan kerupuk amplang Kelompok Wanita Mandiri kepada masyarakat dengan lebih mudah. Untuk membuat bisnis tetap berjalan dengan baik perlu memikirkan strategi promosi dan penjualan. Promosi mutlak harus dilakukan karena dengan adanya promosi bisa memperkenalkan sebuah produk sehingga calon konsumen bisa mengenal produk yang akan ditawarkan. Sedangkan Untuk variabel bauran pemasaran dari indikator harga adalah yang paling terkecil dengan total mean 4,13 dengan kategori tinggi yang artinya harga jual kerupuk amplang yang ditawarkan tidak sesuai dengan kualitas produk serta penetapan harga yang rendah dibandingkan produk pesaing belum tentu dapat menguasai pangsa pasar yang lebih besar. Harga merupakan salah satu penentu keberhasilan suatu perusahaan karena harga menentukan seberapa besar keuntungan yang akan diperoleh perusahaan dari penjualan produknya baik berupa barang atau jasa. Sebelum menentukan harga produk di pasar perlu dipertimbangkan faktor utama jenis biaya yang akan menentukan batasan harga. Menjual produk dengan harga mahal akan beresiko tidak laku dijual dan jika dijual dengan harga murah juga akan berdampak pada persepsi konsumen terhadap kualitas produk yang dijual.

\section{SIMPULAN}

Berdasarkan penelitian yang dilakukan mengenai Persepsi Masyarakat Terhadap Usaha Kerupuk Amplang (Studi Kasus Kelompok Wanita Mandiri Desa Pambang Pesisir) ditinjau dari aspek pemasaran maka dapat diambil kesimpulan sebagai berikut: tanggapan masyarakat tentang Bauran Pemasaran pada Usaha Kerupuk Amplang (Studi Kasus Kelompok Wanita Mandiri Desa Pambang Pesisir) adalah diperoleh dari masing-masing pernyataan indikator tersebut yang berjumlah 4 indikator dengan 8 pernyataan, maka diperoleh total nilai untuk variabel bauran pemasaran yaitu sebanyak 4,25 yang artinya bauran pemasaran yang dilakukan pada Kerupuk Amplang Kelompok Wanita Mandiri Desa Pambang Pesisir dengan kategori sangat tinggi. Sedangkan tanggapan masyarakat mengenai Variabel Bauran Pemasaran yang paling dominan dari masing-masing indikator adalah promosi merupakan salah satu bauran pemasaran yang paling dominan dengan total mean 4,50 dengan kategori sangat tinggi yang artinya masyarakat tertarik dengan promosi yang dilakukan baik secara langsung maupun melalui media sosial. Sedangkan tanggapan masyarakat mengenai Variabel Bauran Pemasaran yang paling terkecil dari masing-masing indikator adalah harga dengan total mean 4,13 dengan kategori tinggi yang artinya harga jual kerupuk amplang yang ditawarkan tidak sesuai dengan kualitas produk serta penetapan harga yang rendah dibandingkan produk pesaing belum tentu dapat menguasai pangsa pasar yang lebih besar. 


\section{DAFTAR RUJUKAN}

A.D Selang, Chistian. (2013) Bauran

Pemasaran (Marketing Mix)

Pengaruhnya Terhadap Loyalitas

Konsumen Pada Fresh Mart Bahu

Mall Manado. Jurnal EMBA, Vol.1

No.3. 71-80.

Assauri, Sofjan. (2010) Manajemen Pemasaran. Edisi Pertama. Cetakan ke-10. Rajawali Pers, Jakarta.

Ginting, Nembah F. Hartimbul. (2011)

Manajemen Pemasaran. Yrama Widya, Bandung.

Praja, Bryan Sacaksana Setya. (2015) Pengaruh Bauran Pemasaran (Marketing Mix) Terhadap Loyalitas Konsumen Produk Fanta PT. CocaCola Amatil Indonesia di Kota Semarang.

Sugiyono. (2012) Metode Penelitian Kuantitatif Kualitatif dan $R \& D$. Alfabeta, Bandung.

----------. (2014) Metode Penelitian Kuantitatif Kualitatif dan $R \& D$. Alfabeta, Bandung.

UKM Riau. (2016) Data UKM Pekanbaru Riau. (http://ukmriau.go.id). Diakses tanggal 27 Februari 2017.

Dinas Komunikasi, Informatika dan Statistik Kabupaten Bengkalis. (2016) Kecamatan Bengkalis. (). Diakses Tanggal 10 Juli 2017. 